\title{
Apresentação
}

\section{Consumo e Subjetividade}

\section{Consumption and Subjectivity}

Thais Alves Marinho

O Dossiê "Consumo e Subjetividade" reúne artigos, a partir de um ponto de vista interdisciplinar, que buscam superar as análises que tomam o consumo meramente por seu caráter hedonista, efêmero e promotor de desagregação social. O esforço conjunto dos(as) autores(as) é no sentido de compreender o fenômeno em suas múltiplas manifestações, privilegiando os significados sociais e os processos simbólicos acionados pelos indivíduos nessa atividade.

Os artigos buscam demonstrar a complexidade do fenômeno a partir do adensamento do saber técnico, que possibilita um ascendente processo de circulação de informações, pessoas, bens, signos e serviços que ultrapassa as fronteiras nacionais, a partir do advento da modernidade. Apesar da crença de que a atual configuração globalizada, que consolida as leis de valor do capitalismo de consumo, vem gerar uma homogeneização da cultura, os textos apresentados demonstram que o acesso aos saberes e aos bens se faz mediante uma processualidade histórica e hierarquizante, estabelecida por uma rede intricada de controles sobre a cognição e a volição dos indivíduos. A partir desse enfoque, os artigos apresentam de forma convergente como o jogo do poder, por meio do consumo, gera um ambiente simbólico marcado tanto pelas desigualdades sociais e simbólicas, por um lado, quanto pela diversidade cultural, por outro.

As análises apresentadas se valem de metodologias, enfoques e objetos diversos; e demonstram que o consumo se estabelece como uma rede de saber social e historicamente instaurado. No entanto, há certo consenso entre elas de que o consumo tem se tornado um fenômeno marcante na sociedade contemporânea e de grande relevância psicossocial, constatando a emergência não só de uma cultura do consumo, mas de uma sociedade do consumo, regulada pela lógica do mundo dos bens, a partir de um sistema de produção e circulação de objetos e bens simbólicos, que se auto-referendam nas identidades e subjetividades dos sujeitos, ao mesmo tempo que as moldam. Os autores e autoras dos textos são de origem geográfica distintas, dialogam com interlocutores nacionais e internacionais, alguns conhecidos dos pesquisadores brasileiros, e outros que não figuram com tanta frequência nos estudos sobre consumo e que merecem maior atenção.

No artigo "Da Terra à Mesa: Narrativas de Consumidores sobre Motivação para o Consumo de Alimentos em 2 Feiras Agroecológicas de Recife", de autoria de Maria Elisa Tavares Moreira, Raquel Aragão Aragão Uchôa Fernandes e Marcelo Machado Martins, 
problematiza-se o consumo sustentável como promotor de melhorias na qualidade de vida. Para tanto, analisam o consumo fora da lógica da indústria cultural consumista, enquanto espaço de institucionalização de práticas sociais que pretendem instaurar novos hábitos nos consumidores ou reforçar a manutenção deles, incluindo uma relação de maior proximidade com os produtores.

$\mathrm{O}$ artigo intitulado "O Consumo Cultural de Jovens na Cultura Hallyu", de Aline Gomes Santana, trata da apropriação da cultura Hallyu por jovens recifenses por meio do consumo de bens culturais, num movimento de reconversão identitária. $\mathrm{O}$ grande motor desse processo de atração às culturas transnacionais seria a interação proporcionada pela cultura digital.

O trabalho de Raquel Aragão Uchôa Fernandes, Maria Lygia Almeida e Silva Koike e Michelle Cristina Rufino Mac sobre "Encarceramento feminino, tráfico de drogas e maternidade: cotidianos subalternos, dentro e fora da prisão" problematiza como o consumo delimita as marcas de subalternidade do cotidiano das mulheres em situação de privação de liberdade no Estado de Pernambuco e seus desdobramentos para o exercício da maternidade.

$\mathrm{O}$ artigo intitulado "Jovens Universitários de Camadas Populares e suas Trajetórias Empreendedoras a partir da Vivência Acadêmica" - de Lidia Alice Medeiros e Patrícia da Rocha Gonçalves identifica o consumo de bens duráveis e serviços, que antes era privilégio das classes médias e alta, como motor das disposições acionadas por universitários/trabalhadores de uma instituição de ensino superior privada da Cidade do Rio de Janeiro ao buscarem a mobilidade social e profissional por meio da qualificação educacional e do empreendedorismo.

$\mathrm{O}$ artigo de Carolina Boari Caraciola, intitulado "A influência da Moda na Sociedade Contemporânea”, busca demonstrar como a moda tem se articulado historicamente aos elementos característicos da Sociedade de Consumo, fundada na efemeridade, na busca incessante por diferenciação e inovação, para se estabelecer enquanto atividade econômica e cultural. No entanto, inova ao realizar uma análise não-determinista da moda como catalisadora da diferenciação, em função de sua forte função comunicacional, por meio de uma lógica fundada na imitação, orientada pela estratificação social, particularmente delimitada a partir de cada contexto cultural.

$\mathrm{O}$ artigo intitulado "Cultura Material e Consumo no Município de Varginha-MG (1882-1920): Os Espaços Exteriores, os Objetos e as Habitações", de Natânia Silva Ferreira, busca apreender, recorrendo a fontes históricas, como se estabelecem as transformações de uma organização social estruturada em torno da ruralidade, que passa a ser impulsionada pela elite para a modernização. $\mathrm{O}$ recorte temporal se dá na passagem para o século XX no município de Varginha, situado ao Sul de Minas Gerais. O impulso de diferenciação da elite não foi suficiente, no entanto, para superar as formas tradicionais e rústicas de lidar com o consumo e a cultura material de parte de seus habitantes, com destaque para os espaços exteriores, os objetos e as habitações.

$\mathrm{O}$ artigo de Mónica Gioconda Izurieta, intitulado “Tejiendo relaciones campo y ciudad, conquistas de mujeres en procesos de producción, circulación y consumo" busca apresentar a experiência 
inovadora de transformação de espaços de consumo a favor de formas de produção e consumo solidárias, sustentáveis e biosseguras. O fenômeno descrito pela autora é fruto da união entre pesquisadores da Universidade Andina Simón Bolívar, junto às mulheres indígenas dos povos Kayambi e Tabacundo e movimentos de consumidores da cidade de Quito, que se posicionaram como protagonistas do processo coletivo de transição nas formas de consumo e produção. A abordagem busca superar as abordagens economicistas sobre o consumo, focando em como as subjetividades sociais dos processos de consumo são potenciais de transformação e capazes de fazer frente aos processos de urbanização acelerado e às agressivas estratégias de penetração do capital na vida cotidiana dos seres humanos e na natureza.

No artigo de autoria de Bianka Rodrigues de Oliveira e Thais Alves Marinho, com o título "A Sociedade do Consumo e o Movimento de Vanguarda: A contradição do Tropicalismo", busca-se analisar as relações entre o Movimento Tropicálica, entendido como expressão do neotribalismo de Maffesoli, e a sociedade de consumo. A abordagem inova ao perspectivar como a constituição identitária aciona necessidades de autocategorizações ontológicas, não supridas pela lógica do capitalismo moderno, promovendo, por um lado, a tendência para a formação das tribos urbanas e, por outro, alimentando a sociedade do consumo pelo acirramento do consumo de bens simbólicos identitários.

$\mathrm{O}$ artigo intitulado "A Presença dos Grupos Primários nas Escolhas de Consumo de Crianças e Adolescentes do Projeto de Apoio à Distancia da ONG 'De Mãos Dadas Pela Vida", de autoria de Alessandro Calidoni, busca promover uma reflexão sobre o universo de constrangimentos institucionais que orientam as escolhas de consumo entre crianças e adolescentes da periferia da região metropolitana de Goiânia, no centro-oeste brasileiro.

Por fim, o artigo intitulado "Consumo e Subjetividade: Do Neotribalismo aos Círculos Viciosos do Consumo", de autoria de Thais Alves Marinho e Paolo Totaro, procura identificar um marco teórico e metodológico para o consumo que seja capaz de compreender o fenômeno desde seu caráter hedonista, que possibilita a sociedade do consumo, até seu potencial de promover integrações sociais, que formalizam relações como as descritas no fenômeno do neotribalismo.

Dossiê Consumo e Subjetividade

Arquivos do CMD, Volume7, N.2. AGo/Dez 2018 